\title{
Effect of Workplace Spirituality on Perceived Organizational Support and Job Performance among University Administrative Employees
}

\author{
Chiyem Lucky Nwanzu \\ Department of Psychology, Delta State University, Nigeria \\ Email: nwanzulc@delsu.edu.ng; nwanzuchiyem@gmail.com \\ Sunday Samson Babalola* \\ Faculty of Management Sciences, Walter Sisulu University, South Africa. \\ Email: babalolass@gmail.com
}

\begin{abstract}
The need to fully exploit human resources for competitive advantage has brought spirituality into the work setting. The study set to examine the predictive relationship workplace spirituality has with perceived organizational support and job performance. The assessment is premised on Rego and Cunha's five-workplace spirituality dimension model. This study adopted a correlational design with a self-administered questionnaire of 118 university administrative employees at a university. The research hypotheses were tested with regression analysis. Results show that composite workplace spirituality correlates positively and significantly with perceived organizational support and job performance. However, only a few of the dimensions show positive and significant results. This study shows that enhancing workplace spirituality improves employees perceived organizational support and job performance. Therefore, it is recommended that human resource management practitioners recognize the influence of workplace spirituality in the effective functioning of the organization.
\end{abstract}

Keyword: Workplace spirituality, Perceived organizational support, Job performance, Affective action theory, Extra-role behavior

\section{INTRODUCTION}

Spirituality, the human craving for connection with the transcendent, the desire to integrate the self into a meaningful whole, and attaining one's potential is gaining research (Bożek et al., 2020; Hvidt et al., 2020). Practical recognition in a work setting as the drive for competitive advantage and performance among organizations demands 
maximum total contribution from human resources'. The value of human resources in achieving effective organizational functioning is testimonial in the literature (Alghamdi, 2020; Fernando et al., 2020). Employees are expected to bring intelligence and whole selves to the organization, thus making spirituality fruitfully accommodated in the workplace (Indradevi, 2020). Since workplace spirituality was adopted as an organizational variable, it has received few research efforts in concept clarification, measurement, search for antecedents, and consequences. However, workplace spirituality literature is in infancy, lacking shared understanding and limited empirical studies (Fanggidae et al., 2020; Indradevi, 2020; ur Rashid et al., 2019). Several researchers (Mahesh \& Saravanakumar, 2020) have suggested further research on direct, mediating, and moderating relationships workplace spirituality has with other organizational variables. This study addresses the gap in workplace spirituality relationship with perceived organizational support (POS) and job performance.

There is limited literature on the relationship between workplace spirituality, POS, and job performance. The near absence of research on workplace spirituality and POS is of concern as the latter is theoretically expected to be a natural outcome of workplace spirituality. Job performance is one variable that has many implications for the organization. It predicts and mediates the relationship between many work attitudes and organizational performance (Mahesh \& Saravanakumar, 2020; Tarmidi \& Arsjah, 2019). Among the few existing studies on workplace spirituality and job performance, three related concerns arise from measuring the latter variable. The first concern is the non-documentation of either the sources or the measures used for the variables (Fanggidae et al., 2020; Iksan et al., 2020; Suherman, 2020; Tantua \& Osuamkpe, 2020). Lack of disclosure of measures used puts doubt on the study's validity and could impede the grouping of such researches for several purposes, such as meta-analysis.

Another concern is that most studies that adopted job performance measures do not represent the current conceptualization of job performance that covered task performance and contextual performance. Although (Moon et al., 2020) adopted Williams and Anderson's (1991) scale that covered task performance and contextual performance, the latter subscale was selected. Petchsawang and Duchon (2012) assessed work performance using the sampled company's standard evaluation instrument and procedures in their research. Undoubtedly, the study's findings would be of applied value to the organization studied but limited in generalizability and not open to comparison with related studies results. The third concern is about the efficacy of measures adopted in the studies as there were not scales that have received full acceptance in terms of the soundness of their psychometric properties. In other words, they are not technically acceptable survey instruments. A scale is technically sound if it meets at least four characteristics. Multiple items measured its constructs; an attempt 
was made to assess the instrument's psychometric properties; its use was described in a refereed journal and could be reconstructed (Zmud \& Boynton, 1991). The job performance measurements in related studies have implications for the body of knowledge on workplace spirituality- job performance relationship. The presentation above established the need for more education on workplace spirituality's effect on POS and job performance. Consequently, this study examined the associations with an instrument that mostly met the present and widely accepted conceptualization of job performance.

\section{Workplace Spirituality}

\section{LITERATURE}

Workplace spirituality is among organizational behavior variables that have attracted many perspectives and definitions (ur Rashid et al., 2019). This situation could be adjudged normal for now as the concept is at its infancy with the possibility of further exploration that would lead to a conceptual consensus level. As a concept and phenomenon, workplace spirituality is gaining tremendous interest among academics (Bożek et al., 2020; Hvidt et al., 2020; Rathee \& Rajain, 2020). Practitioners and empirical work on the variable are growing in leaps and bounds as many organizations incorporate it into their culture. Many corporations are now explicitly using the word "spirituality" in their internal and external literature and initiate and encourage spiritual activities (Indradevi, 2020). Smith and Rayment (2007) defined workplace spirituality as a state or experience of employees who can provide them the direction or meaning or give feelings on understanding, support, inner wholeness, or connectedness. According to Giacalone and Jurkiewicz (2003), it is a structure of organizational values observable in the culture that advanced employees' experience of transcendence through the work process, facilitating their sense of interconnectedness to others in a manner that gives feelings of wholeness and happiness.

Similarly, workplace spirituality is employees' inner lives, nourished by meaningful work experiences in the community context (Ashmos \& Duchon, 2000; Robbins \& Judge, 2019). The cited definitions of workplace spirituality are a mixture of both employees' experience and organization. That WPS has several explanations expressing the boundary setting problem that characterized some organizational behavior, which emanates from the dynamic, interactive features of organizational variables and the analytical nature of human thinking. However, in this study, workplace spirituality refers to an employee's desire and attempts to live their values more fully in the workplace and organizational effort to support their spiritual growth (Bella et al., 2018). 
Lack of consensus on how to conceptualize WPS is not without outcome, as it has resulted in various models representing different ways of thinking about these variables (Rathee \& Rajain, 2020). These models, which primarily represent national culture differences, are inherently valuable for guiding research processes, such as data collection, data analysis, and interpretation of results. The availability of many WPS models and their associated components demonstrate a widespread interest in and relevance of workplace spirituality. However, multiple WPS models imply a lack of a general theory on the concept. A conspicuous feature of WPS models is the overlap among the dimensions. A remark that can be made about the characters is that it points to the possibility of a general theory of workplace spirituality, which can be achieved through a combination of the existing models. Such an approach impacts some difficulties and limitations in interpreting results and comparing studies on workplace spirituality.

However, this study adopted Rego and Cunha's (2008) five-dimensional model. The team's sense of community expresses team spirit, mutual care among employees, sense of community, and shared purpose. Alignment between organizational and individual values refers to the unity between corporate profits and employees' inner lives. A sense of contribution to the community represents employees feeling that the job being done benefits the community. A sense of enjoyment at work represents an expression of an intention of joy and pleasure at work. Opportunities for inner life refer to how the organization respects the spirituality and spiritual values of the employees. This framework was adopted to synthesize and integrate a few other models, making it a comprehensive and complete representation of the varied perspective to conceptualize workplace spirituality, aside from incorporating diverse models (Ashmos \& Duchon, 2000; Milliman et al., 2003). Rego and Cunha's model brings in workplace spirituality's three levels (individual, group, and organization). Achieving this is well recommended in WPS literature.

\section{Perceived organizational support}

The healthy employee-employer relationship is necessary for organizational performance as it indicates a conducive, harmonious work environment that gives impetus to productive work behavior. One gauge of this relationship is expressed in the concept of perceived organizational support (POS), which refers to the degree to which employees perceived the organization cares about their well-being and values their contribution (Robbins et al., 2018). Employees can infer how much their organizations care about their well-being from values, norms, beliefs, practices, and structures. Employees perceive their organization as supportive when rewards are deemed fair, and when they participate in decision-making, their supervisors are concerned about their 
welfare. Other factors that influence employees' perception of support from their organizations are human resource planning, training and development, and performance evaluation (Al-Hawary \& Nusair, 2017). POS is considered mainly from social exchange theory; employees who received good support from their organizations will reciprocate it by engaging in productive work behavior. As Beheshtifar and Zare (2012) noted, how employees interpret how an organization values them is vital for determining their attitudes benefiting the organization.

\section{Job Performance}

Job performance is among the organizational variables that have attracted much theoretical and empirical concern, particularly among industrial and organizational psychologists (Davidescu et al., 2020). Job performance represents the value of employee behaviors that contribute to organizational goal accomplishment (Colquitt et al., 2019). Viswesvaran and Ones (2000) approached individual performance as social actions, practices, and outcomes that employees engage in or bring about that are linked with and contribute to organizational goals. As the definitions indicate, job performance has both behavioral (process) and outcome aspects. These two aspects are related as the former is affected by other determinants aside from the latter.

Job performance implies both the employee and the organization. It justifies employee membership to the organization, and its existence as the aggregation of job performance represents organizational performance. A few models have been proposed on job performance, and all necessarily expressed two categories of variables that covered task performance and organizational citizenship behavior (OCB). Task performance refers to employee behaviors directly involved in transforming corporate resources into the goods or services that the organization produces (Colquitt et al., 2019). The proficiency job incumbent carries out officially recognized activities as aspects of their job (Landy, 2019). It is a job performance dimension that deals with the quantity and quality of the goods produced or services delivered by the employee. Necessary antecedents are procedural and declarative knowledge, ability, and job experience. Organizational citizenship behavior refers to discretionary behavior that is not part of an employee's formal job requirements and contributes to the workplace's psychological and social environment (Robbins \& Judge, 2019). Employees' positive, constructive, and voluntary behavior is directed at co-workers and the organization with desirable implications (Colquitt et al., 2019).

Among the several models of OCB is the Organ's (1988) five-dimension model of OCB. Williams and Anderson (1991) classified OCB into two groups (OCBindividual and OCB-organization). The former refers to OCB directed at the organization, including employee attendance at work above the norm. The latter, OCB- 
individual, refers to OCB directed at co-workers, which involves helping an absent coworker. Employee exhibition of task performance and OCB is essential for achieving organizational objectives as task performance is concerned with necessary behaviors to complete job tasks. In contrast, $\mathrm{OCB}$ is required to protect and advance the organization's work, social, and psychological environments.

\section{Workplace Spirituality and Perceived Organizational Support}

Workplace spirituality is characterized by employees' experience and work environment that can help assess how the organization cares for employees' well-being and values their contribution. An aspect of the work environment that has received much support influencing employees' perceived organizational support is organizational justice. Organizational justice is an individual's perception of corporate fairness regarding distributive, procedural, and interactional justice (Robbins et al., 2018). Another employee's experience that workplace spirituality symbolizes is organization-based self-esteem. Organization-based self-esteem refers to the degree to which an employee believes themself necessary, meaningful, effectual, and worthwhile in the organization they work for (Pierce et al., 1989). A significant relationship has been observed between organization-based self-esteem and POS (Sayadi et al., 2015). As indicated earlier, a few related studies could be identified as there is limited study on workplace spirituality and POS. For instance, workplace spirituality correlated positively with POS (Afsar \& Badir, 2017).

Although study on the relationship between workplace spirituality and POS conspicuously lacks in the literature, the latter has a record of predicting in a desirable direction some other workplace attitudes that include organizational commitment, job satisfaction, psychological empowerment, and employee engagement (Choi, 2019; Imran et al., 2020; Maan et al., 2020). Consequently, it was hypothesized that:

Hypothesis 1: Workplace spirituality positively predict POS

\section{Workplace Spirituality and Job Performance}

The relationship between workplace spirituality and job performance results in studies as the theoretical proposal and anecdotal claims that workplace spirituality benefits the individuals and the organizations need sufficient empirical testing. Workplace spirituality represents some factors that researchers have found to be precursors of job performance. Workplace spirituality indicates the recognition of employee spiritual life. Such experience is an essential source of employee motivation, which has been well reported to influence job performance desirably (Girdwichai \& Sriviboon, 2020; Kuswati, 2020). Workplace spirituality also indicates the organization's consideration of employee well-being. A few studies (Aboobaker et al., 
2019) revealed that workplace spirituality significantly predicts employees' well-being. Haddon (2018) reported that employee well-being impacts individual, team, and organization productivity.

Workplace spirituality expresses alignment between the employee and the organization. In agreement with the various constituents, studies on workplace spirituality and job performance mainly indicate an organizationally desirable relationship. Tayebiniya and Khorasgani (2018) study revealed a significant correlation between religiosity at work, its dimensions that covered meaningful work, a sense of connection and positive social relations with a co-worker, and the individual's alignment with the values of the organization and job performance. Mariani et al. (2020) reported that workplace spirituality positively and significantly associates with OCB. Such experience positively influenced innovative work behavior (Akhtar et al., 2019), job satisfaction, organizational commitment, and job performance (Park et al., 2020; Rajper et al., 2020).

Workplace spirituality positively influenced innovative work behavior (Ranasinghe \& Samarasinghe, 2019), and OCB and work innovative behavior have been identified as aspects of job performance (Colquitt et al., 2019). Workplace spirituality is connected to reducing work stress (Koti \& Kinange, 2021); the latter is employee experience widely documented to impact job performance negatively and is highly undesirable for organization functioning (Agu, 2021; Tamunomiebi \& Mezeh, 2021). Workplace spirituality significantly affects job performance (Biswakarma, 2018; Iksan et al., 2020; Jena, 2021). Employee's spirituality, workplace spirituality, and perceived organizational performance move in the same direction (Salcedo \& Lazatin, 2021).

Affective event theory (Weiss \& Cropanzano, 1996) explained the widely reported positive relationship between workplace spirituality and job performance. The authors proposed that events (positive or negative) in the workplace cause emotional reactions from the employees that influence workplace attitudes and behavior. Accordingly, workplace spirituality (recognizing an employee's spiritual life in the work setting) is a positive experience that would arouse positive emotion that can potentially affect specific behaviors such as job satisfaction and job performance. In support of the theory, Okeke et al. (2016) observed that the work environment elicits affective reactions, affective reactions influence job satisfaction, emotional exhaustion negatively affects job satisfaction, and employees' psychological well-being influences their job performance. Also, (Zoghbi-Manrique-de-Lara \& Sharifiatashgah, 2020) observed a significant positive relationship between relational conflict, privacy invasion, crowding perceptions, and OCB-I. Besides job performance, workplace spirituality was reported to correlate in organizationally desirable direction with work behavior such as 
employees' well-being and intention to stay (Aboobaker et al., 2019), employees' cynicism, and intent turnover (Shrestha \& Jena, 2021). Therefore, it was hypothesized that:

Hypothesis 2: Workplace spirituality positively predicts job performance.

This study framework is presented in figure 1. The relationship expressed in the chart is recursive (unidirectional); workplace spirituality impacts POS and job performance, not the other way around.

Figure 1. The Recursive Relationship between Workplace Spirituality on POS and Job Performance.

- Perceived organizational support

\begin{tabular}{|c|c|}
\hline Workplace spirituality & support \\
\hline $\begin{array}{l}\text { - Team's sense of } \\
\text { community } \\
\text { - Alignment between } \\
\text { organizational and } \\
\text { individual values } \\
\text { - Sense of contribution of }\end{array}$ & Job Performance \\
\hline $\begin{array}{l}\text { the community } \\
\text { - Sense of enjoyment at } \\
\text { work } \\
\text { - Opportunity for the inner } \\
\text { life }\end{array}$ & $\begin{array}{l}\text { - In-role performance } \\
\text { - Extra-role behavior } \\
\text { (individual) } \\
\text { - Extra-role behavior } \\
\text { (organization) }\end{array}$ \\
\hline
\end{tabular}

\section{RESEARCH METHODOLOGY}

\section{Participants}

One hundred and eighteen support staff of Delta State University, Nigeria, participated in the study. Workplace spirituality is gaining more attention in university settings. For instance, the institution recently initiates and encourages spiritual activities that allow employees to take some minutes of their work for morning devotion before commencing the day work and regularly organize "praise da" for staff and students.

The sample size of 118 was considered satisfactory. It was incongruent with Dewberry's (2004) recommendation that when the effect size expected is unknown, the sample size required is medium effect size. Therefore, the sample size chosen has above $80 \%$ power of detecting a significant association between each pair ( $\mathrm{p}<0.05$ level) of significance if such an association exists. The sample comprises 58\% males, $42 \%$ 
females, $78 \%$ unmarried, and $22 \%$ married. Their age mean was 40.19 years (SD, 10.25; range, 42 years). Sixty-nine percent of the participants hold a first degree or the equivalent. Nine percent have post-graduate degrees, while $21 \%$ hold certificates lower than first degree. Thirty-six percent is on grade level 7 and below (junior staff member), while $64 \%$ is on grade level 8 and above (senior staff member). The sample is from a literate population; thus, it explained the high return and available questionnaire. It also gives validity to the self-report measure adopted.

\section{Measurement}

The scale developed by Rego and Cunha (2008) was adopted for workplace spirituality. The measure has 17-item measuring five dimensions that covered the team's sense of community, 5-item; alignment between organizational and individual values, 5-item; a sense of contribution to the community, 3-item; and a sense of enjoyment, 2item; and opportunities for the inner life, 2-item. The 8-item perceived organizational support scale (Eisenberger et al., 1997) was adopted from a confirmatory analysis on the original 36-item perceived organizational support scale (Eisenberger et al., 1986); the items were the highest loaded. The short form 8 -item version has been reported to be of satisfactory psychometric properties. Williams and Anderson's (1991) 21-item job performance scale, which was on in-role/task performance (7-item) and OCB (14-item). The measuring scale was well-known along the OCB-I (7-item) dimensions and OCB$\mathrm{O}$ (7-item) in line with the OCB model. The three measures are widely used in studies, and they are well associated with good psychometric properties (Biswakarma, 2018; Chia \& Kee, 2018; Imran et al., 2020). The 5-point Likert summated rating scale of 5strongly agree, 4-agree, 3-undecided, 2-disagree, 1-strongly disagree was adopted to generate enough variability in response that gives validity to statistical outputs (Nwanzu $\&$ Babalola, 2020). For all the scales, scores were computed by averaging each participant's reactions to the items.

\section{Design and Statistical Tool}

The research design was cross-sectional as data were collected at a single point in time. These research designs enable the measurement of several different variables simultaneously (Howitt \& Cramer, 2017). Data were collected, analyzed, and interpreted at the individual level, besides a few statistical procedures. The mean and the standard deviation were used to describe respondent characteristics on the variables. The test of internal reliability was achieved with Cronbach's alpha.

Similarly, Cronbach alpha was also used to test for convergent validity, an aspect of construct validity. The hypotheses were tested with appropriate regression analysis, as the study examines predictive relationships among variables and the various 
requirements such as interval level data met regression application. Different statistical procedures used to test the regression analysis assumptions include the Durbin-Watson test and variance inflation factors (VIFs). The study adopted Cohen's (1988) approach to effecting size measurement and interpretation. The statistical analysis was done using IBM-SPSS version 26 software.

\section{Control Variables}

The study incorporated gender as a control variable in the relationship between workplace spirituality and POS. Social role theory (Eagly \& Wood, 2012) explained gender as a control variable in the relationship. Social role theory acknowledges gender differences in behavior in social settings, which emanates from this approach, working in a formal organization the right for men and a privilege for women. This belief has the potential for differences in the demand and expectations the sexes would have on their employing organizations. In support of this argument, some researchers (such as Kaur, 2017) have reported that women perceived more significant help from their employing organizations when compared to men. The study also used education as a control variable in workplace spirituality- job performance relationship. The human capital theory (Becker, 2009) offered theoretical bases for education as a control variable in the relationship. The theory proposes, and with empirical support, that as knowledge, skill, and abilities increase with higher education, job performance also improved (Perera \& Weerakkody, 2018).

\section{Common Method Variance}

The design of this study involves procedures that control for common method variance. The cover letter attached to the questionnaires informed the participants of their anonymity and confidentiality of collected data. The letter also contained the phrase "there is no wrong or right answer" to urge the respondents to answer questions as honestly as possible (Rodríguez-Ardura \& Meseguer-Artola, 2020). The rating pattern for the measure followed the Likert method of summated rating with five response options. A 5-point rating scale typically gives sufficient discrimination (generates enough variability in response) and is easily understood by survey participants. Making acceptable variance among respondents through scaling gives validity to statistical outputs and controls the central tendency. Corollary to the use of 5- points rating, this study adopted a balanced response format of an equal number anchored by opposite poles, with midpoints. Compared to the unbalanced response format scaling, the balanced rating format reduces potential bias (Brace, 2018). Finally, each question that measures POS, workplace spirituality, and job performance items were on a separate sheet of paper with introductory notes and instructions worded 
differently in the study. This approach creates a physical gap that curtails the flow of thought from one variable to another (Rodríguez-Ardura \& Meseguer-Artola, 2020).

\section{Procedure}

The researchers administered the survey questionnaires to the participants at the workplace. The convenience sampling technique was used to collect the data based on participants' availability. The use of non-random samples is a common feature in organization studies, particularly in this research location, as sampling frames are often unavailable or extremely difficult to access. A total of 145 questionnaires were distributed; within two weeks, 118 were received and were used for data analysis. This return rate is satisfactory when considered the widely expressed declining trend of response rates (Leeper, 2019; Luiten et al., 2020). This return rate is acceptable as it exceeded survey response rate levels and trends in organizational research (Baruch \& Holtom, 2008). Accurately, Baruch and Holtom (2008) reported an average response rate of $52.7 \%$ (SD. 20.4) and $35.7 \%$ (SD 18.8) for studies that utilized data collected from individuals and organizations, respectively.

\section{RESULTS AND ANALYSIS}

The demographic characteristics of the participants are presented in Table 1. The table shows that most participants are male, those within the age bracket of 41 and 50, married, first degree and equivalent certificate holders, and staff members on grade level 8 and above (senior staff). 
Table 1 Demographic Profiles of the Participants

\begin{tabular}{llcc}
\hline \multicolumn{1}{c}{ Variable } & \multicolumn{1}{c}{ Categories } & Number & Percentage \\
\hline Gender & Male & 118 & \\
& Female & 68 & 58 \\
& & 43 & 42 \\
\hline Age & $\leq 21-30$ & 118 & \\
& $31-40$ & 2 & 2 \\
& $41-50$ & 25 & 21 \\
& $51-60$ & 60 & 51 \\
Marital status & & 31 & 26 \\
& Married & 118 & \\
& Unmarried & 92 & 78 \\
\hline Education & $\leq$ First-degree certificate & 26 & 22 \\
& First-degree/ equivalent certificate & 118 & \\
& Post-graduate certificate & 25 & 22 \\
& & 11 & 69 \\
& & 118 & \\
\hline Rank/designation & Grade level 7 and below (Junior & 42 & 36 \\
& Staff) & 76 & 64 \\
\hline
\end{tabular}

\section{Reliability and Validity Tests}

The authors tested for the reliability for each multiple-item scale tested with Cronbach's alpha. The results are reported in Table 2. Overall, substantial reliability range from $\alpha=.60$ to $\alpha=.88$. The obtained alpha statistics also offer support for the scales' convergent validity (Field, 2018). The various job performance dimensions correlate as theoretically expected, therefore establishing construct validity for the scale.

Similarly, the authors achieved content validity by adopting item scales from the literature (Mirjana et al., 2018). The mean scores ranged between 3.27 and 3.94, which on a 5-point scale, indicate average scores, as shown in Table 2. Male participants had higher scores in all the factors. 
Table 2 Mean, Standard Deviation, and Cronbach's Alpha on the Studied Variables

\begin{tabular}{ccccc}
\hline & $\overline{\mathrm{x}}$ & SD & $\alpha$ & No of Items \\
\hline TSC & 3.68 & 81 & .83 & 5 \\
A0IV & 3.31 & .83 & .73 & 5 \\
SCC & 3.54 & .97 & .60 & 3 \\
SEW & 3.59 & 1.10 & .75 & 2 \\
OIL & 3.27 & .96 & .66 & 2 \\
WPS & 3.45 & .60 & .83 & 17 \\
POS & 3.35 & .92 & .88 & 8 \\
IRB & 3.94 & .69 & .81 & 7 \\
ERB-in & 3.48 & .71 & .75 & 7 \\
ERB-org & 3.84 & .70 & .68 & 7 \\
JP & 3.67 & .60 & .84 & 21 \\
\hline
\end{tabular}

NOTE. TSC = Team's sense of community; AOIV = Alignment between organizational and individual values; $\mathrm{SCC}=$ Sense of contribution to community; SEW = Sense of enjoyment at work; OIL = Opportunity for the inner life; WPS = workplace spirituality; POS = perceived organizational support; IRB = In-role behavior; ERB-in = Extra-role behavior-individual; ERB-org = Extra-role behavior-organization; JP = Job performance

Table 3 shows the inter-correlation coefficients of the studied factors. The degree of relationship between the predictor and the criterion variables was modest. Thus, indicating the absence of multicollinearity in the model. The research used regression analysis as a statistical tool to test the hypotheses. While a parametric test assumption associated was taken into consideration in the design of the study. For instance, the data collected were independent of each other, which met the individual responsibility requirement. The Likert scale format adopted met the demand for interval scaling. Durbin-Watson test statistics ranged between 1.59 and 2.25, and as Field (2018) suggested, these values are within the acceptable level concerning autocorrelation. The observed variance inflation factors were all below 10, indicating the absence of collinearity in the data (Field, 2018; Hayes, 2017). 
Table 2 Correlation Matrix on the Studied Variables

\begin{tabular}{|c|c|c|c|c|c|c|c|c|c|c|c|c|}
\hline & TSC & AOIV & $\mathrm{SCC}$ & SEW & OIL & WPS & POS & IRB & $\begin{array}{c}\text { ERB- } \\
\text { in }\end{array}$ & $\begin{array}{c}\text { ERB- } \\
\text { org }\end{array}$ & JP & Gen \\
\hline \multicolumn{13}{|l|}{ TSC } \\
\hline AOIV & $.22^{*}$ & & & & & & & & & & & \\
\hline $\mathrm{SCC}$ & $.32^{* *}$ & $.38^{* *}$ & & & & & & & & & & \\
\hline SEW & .13 & $.28 * *$ & $.21 *$ & & & & & & & & & \\
\hline OIL & .14 & $.20^{*}$ & .04 & $.25^{* *}$ & & & & & & & & \\
\hline WPS & $.63^{* *}$ & $.69^{* *}$ & $.63^{* *}$ & $.49 * *$ & $.38^{* *}$ & & & & & & & \\
\hline POS & $.20^{*}$ & $.56^{* *}$ & $.26^{* *}$ & $.41 *^{*}$ & .12 & $.51^{* *}$ & & & & & & \\
\hline IRB & $.32^{* *}$ & -.01 & .11 & .05 & .10 & $.23^{*}$ & -.01 & & & & & \\
\hline ERB-in & $.26^{* *}$ & $.20^{*}$ & $.29^{* *}$ & .05 & .10 & $.33^{*}$ & .19 & $.39^{* *}$ & & & & \\
\hline ERB-org & $.29^{* *}$ & $.20^{*}$ & .17 & .08 & .19 & $.32^{* * *}$ & .17 & $.53^{* *}$ & $.45^{* *}$ & & & \\
\hline $\mathrm{JP}$ & $.28^{* *}$ & $.19^{*}$ & $.22^{*}$ & .08 & .16 & $.32^{* *}$ & $.23^{*}$ & $.54^{* *}$ & $.85^{* *}$ & $.82^{* *}$ & & \\
\hline Gen & $-.29^{*}$ & -.14 & -.08 & -.11 & -.03 & $-.22^{*}$ & -.15 & -.16 & -.15 & -.06 & -.10 & \\
\hline Edu & -.11 & -.08 & -.02 & -.01 & -.05 & -.03 & .01 & $-.19^{*}$ & -.06 & -.10 & -.11 & .05 \\
\hline \multicolumn{13}{|c|}{$\begin{array}{l}\text { NOTE. } *=\mathrm{p}<05 ; * * \mathrm{p}<01 ; \mathrm{TSC}=\mathrm{Team} \text { 's sense of community; AOIV = Alignment between } \\
\text { organizational and individual values; SCC = Sense of contribution to community; SEW = } \\
\text { Sense of enjoyment at work; OIL = Opportunity for the inner life; WPS = workplace spirituality; } \\
\text { POS = perceived organizational support; IRB = In-role behavior; ERB-in = Extra-role } \\
\text { behavior-individual; ERB-org = Extra-role behavior-organization; JP = Job performance; Gen } \\
=\text { Gender; Edu = Education }\end{array}$} \\
\hline
\end{tabular}

\section{Hypotheses Testing}

Multiple regression analysis in Table 4 shows POS predicted from dimensions of workplace spirituality. Team's sense of community, $B(118)=.06 p>.05$, alignment between organizational and individual values, $B(118)=.52<.05$; sense of contribution to the community, $B(118)=-.10 p>.05$ sense of enjoyment at work, $B(118)=.23 p$ $<.05$, and opportunity for the inner life, $B(118)=-.01 p>.05$. The small difference between $R^{2} .39$ and adjusted $R .36$, which is 0.03 , indicates a good cross validity; this model can apply to other samples from the same population. As revealed by the b-values, perceived organizational support increases by $6 \%, 52 \%, 1 \%, 23 \%$, and $-1 \%$ for every one unit increase in team's sense of community (TSC), alignment between organizational and individual values (AOIV), sense of contribution to the community (SCC), sense of enjoyment at work (SEW), and opportunity for the inner life (OIL) respectively. The results indicate that of the five dimensions, only two, alignment between organizational and individual values and sense of enjoyment at work, were a significant positive predictor of POS. It also revealed that a sense of contribution to the community dimension negatively predicts POS. Besides, two of the dimensions had a 
weak, non-significant negative predicted relationship with POS. $\beta$ values show that POS's largest influence was aligning organizational and individual values, accounting for a $42 \%$ variance.

Statistics at the bottom of Table 4 shows the combined contribution of the five workplace spirituality dimensions on POS, $R=.62, R^{2}=.39, p<.05$. The $R^{2}$ value indicates that workplace spirituality as a composite explained $39 \%$ variance in POS. As symbolized by the $R^{2}$, the effect size statistic indicates a large effect size (Cohen, 1988), which means that workplace spirituality has a substantial and important contribution to employees' POS level. The $F$-ratio, also significant at .05 , indicates that the model is good; POS can be predicted from workplace spirituality. Therefore, hypothesis one was accepted.

Table 3 Multiple regression analysis of the predictive relationship of workplace spirituality with POS

\begin{tabular}{lccccc}
\hline & & \multicolumn{5}{c}{ POS } \\
& $B$ & $S E$ & $\beta$ & Part Correlation & VIF \\
\hline TSC & .05 & .09 & .04 & .05 & 1.19 \\
AOIV & .52 & .09 & $.47^{* *}$ & .42 & 1.26 \\
SCC & -.01 & .08 & -.01 & -.008 & 1.26 \\
SEW & .23 & .06 & $.27 * *$ & .26 & 1.15 \\
OIL & -.01 & .07 & -.01 & -.01 & 1.12 \\
GENDER & -.08 & .14 & -.04 & -.04 & 1.06 \\
\hline
\end{tabular}

Note. $F=14.77, R=.62 * *, R^{2}=.39$, Adjusted $R^{2} \cdot 35$, (Durbin Watson, 1.58 ), ** $\mathrm{p}<.05$ (Twotailed); Variance inflation factors (VIF); TSC = Team sense of community; AOIV = Alignment between organizational and individual values; $\mathrm{SCC}=$ Sense of contribution to the community; SEW = Sense of enjoyment at work; OIL = Opportunity for the inner life.

Statistics in Table 5 show the predictive relationship workplace spirituality has with job performance. As indicated by the $R$-value of .37 , the relationship between workplace spirituality and job performance was modest, positive, and significant at $p$ $<.05$. The variance test analysis, $F(4 ; 118)=2.81, p<0.05)$, indicated that the model was good and that job performance can predict workplace spirituality. Therefore, hypothesis 2 was accepted. Of the various relationships expressed in Table 5, only three were significant at $\mathrm{p}<.05$. Specifically, TSC had a positive and significant predictive relationship with job performance, in-role behavior, and extra-role behavior organization. SCC had a positive and significant relationship with extra-role behavior individuals. AOIV had a negative predictive relationship with job performance and inrole performance. SCC had a negative predictive relationship with job performance and 
extra-role behavior-organization. SEW had a negative predictive relationship with job performance, in-role performance, extra-role behavior (individual and organization). However, the combined contribution of the five dimensions on in-role performance $(R$ $=.35, p<.05)$, extra-role behavior-individual $(R=.35, p<.05)$, and extra-role behavior organization $(R=.36, p<.05)$ were positive and significant.

The variance in job performance, in-role performance, and extra-role behaviorindividual, extra-role behavior-organization explained by the workplace spirituality dimensions indicated by the part correlation statistics ranged between 1 to $30 \%$. The effect size of in-role performance and extra-role behavior-individual was small, while extra-role behavior-organization was medium. As revealed by the $B$-value, job performance increases by $20 \%,-2 \%, 1 \%,-6 \%,-2 \%$, and $5 \%$ for every one-unit increase in TSC, AOIV, SCC, SEW, and OIL dimensions of workplace spirituality respectively. 
Table 4 Multiple Regression Analysis of Workplace Spirituality's Predictive Relationship with Job Performance, In-Role Performance, Extra-Role Behavior-In, and Extra-Role Behavior-Org

\begin{tabular}{|c|c|c|c|c|c|}
\hline & Variable & $B$ & $\beta$ & $\mathrm{PC}$ & VIF \\
\hline \multirow[t]{8}{*}{ Job performance } & TSC & .11 & $.18^{* *}$ & .14 & 1.19 \\
\hline & AOIV & .05 & .07 & .08 & 1.28 \\
\hline & SCC & .08 & .12 & .11 & 1.24 \\
\hline & SEW & -.01 & -.02 & -.02 & 1.14 \\
\hline & OIL & .08 & .13 & .12 & 1.12 \\
\hline & Gender & -.06 & -.05 & -.05 & 1.06 \\
\hline & EDU & -.08 & -.07 & -.07 & 1.03 \\
\hline & \multicolumn{5}{|c|}{$F=2.04, \mathrm{R}=.34^{* *}, R^{2}=.12$, Adj. $R^{2}=.06(\mathrm{DW}, 2.33)$} \\
\hline \multirow{8}{*}{$\begin{array}{l}\text { In-role } \\
\text { performance }\end{array}$} & TSC & .24 & $.28 * *$ & .26 & 1.19 \\
\hline & AOIV & -.09 & -.11 & -.10 & 1.26 \\
\hline & SCC & .02 & .02 & .02 & 1.24 \\
\hline & SEW & .001 & -.001 & .001 & 1.14 \\
\hline & OIL & .05 & .07 & .07 & 1.12 \\
\hline & Gender & -.15 & -.11 & -.10 & 1.06 \\
\hline & EDU & -.19 & -.13 & -.13 & 1.03 \\
\hline & \multicolumn{5}{|c|}{$F=2.74, \mathrm{R}=.39^{* *}, R^{2}=.15, \operatorname{Adj} . R^{2}=.09(\mathrm{DW}, 2.06)$} \\
\hline \multirow[t]{8}{*}{ ERB-in } & TSC & .12 & .13 & .12 & 1.19 \\
\hline & AOIV & .06 & .07 & .06 & 1.26 \\
\hline & SCC & .16 & $.21 * *$ & .19 & 1.24 \\
\hline & SEW & -.04 & -.06 & -.06 & 1.14 \\
\hline & OIL & .06 & .08 & .07 & 1.12 \\
\hline & Gender & -.15 & -.10 & -.10 & 1.06 \\
\hline & EDU & -.03 & -.02 & -.02 & 1.03 \\
\hline & \multicolumn{5}{|c|}{$F=2.44, R=.37^{* *}, R^{2}=.14$, Adj. $R^{2}=.08(\mathrm{DW}, 2.44)$} \\
\hline \multirow[t]{8}{*}{ ERB-org } & TSC & .18 & $.21 * *$ & .19 & 1.19 \\
\hline & AOIV & .09 & .11 & .10 & 1.26 \\
\hline & SCC & .03 & .04 & -.03 & 1.24 \\
\hline & SEW & -.01 & -.02 & -.02 & 1.14 \\
\hline & OIL & .10 & .13 & .12 & 1.12 \\
\hline & Gender & .01 & .01 & .01 & 1.06 \\
\hline & EDU & -.09 & -.06 & -.06 & 1.03 \\
\hline & \multicolumn{5}{|c|}{$F=2.09, R=.35^{* *}, \mathrm{R}^{2}=.12, \operatorname{Adj} . R^{2}=.06(\mathrm{DW}, 2.25)$} \\
\hline
\end{tabular}

Note: ERB-in = Extra-role behavior- individual; ERB-org = Extra-role behavior-organization; TSC $=$ Team sense of community; AOIV = Alignment between organizational and individual values; $\mathrm{SCC}=$ Sense of contribution to the community; SEW = Sense of enjoyment at work; $\mathrm{OIL}=$ Opportunity for the inner life; EDU = Education; DW = Durbin Watson. 


\section{DISCUSSION AND CONCLUSION}

This study investigates the predictive relationship workplace spirituality has with POS and job performance. As a phenomenon, spirituality is inherent in humans and has a far-reaching influence on the individual perspective and approach to life and existence issues. However, the theoretical discussion of spirituality as an organizational variable is undoubtedly at infancy but with the accumulating body of knowledge implicating workplace spirituality as a desirable employee experience. This study aimed to contribute to the emerging knowledge necessary to manipulate workplace spirituality for beneficial organizational outcomes. Thus, the research proposed gender and educational qualifications were theoretically control variables. Still, the analysis of these variables revealed a non-significant relationship with the criteria variables (POS, task performance, and in-role performance).

The two hypotheses tested received support from data analysis as workplace spirituality positively and significantly predicts POS and job performance. However, studies with and without the control variables (Caesens et al., 2019) showed identical results. This result confirms similar findings from few related studies, particularly on job performance in the extant literature (Biswakarma, 2018; Iksan et al., 2020; Jena, 2021; Salcedo \& Lazatin, 2021; Tayebiniya \& Khorasgani, 2018). The observation that workplace spirituality enhancing POS and job performance outcomes showed that workplace spirituality experience represents many positive experiences such as recognition, organizational identification, and social support that have implications for desirable organizational outcomes. Affective emotion theory also explains the positive effect of workplace spirituality on POS and job performance.

Further analysis revealed that only workplace spirituality dimensions of enjoyment at work and inner life opportunities had a positive and significant predictive effect on POS. The two aspects accounted for a 68\% variance in POS. POS was negatively related to the community's sense of contribution and opportunity for the inner life. This finding revealed that POS is enhanced by the experience of workplace spirituality aspects that directly benefit the individual. This observation reflects a concern for the self, which is a salient attribute of humans. Regression of workplace spirituality dimensions on job performance dimensions revealed that only three were positive and significant of the fifteen relationships. The analysis also revealed that some of the links were negative, although not substantial. The observed negative correlation between some dimensions of workplace spirituality and job performance is not out of place. Bandsuch and Cavanagh (2005) suggested that specific potential threats like dissension, discrimination misuse, and triviality are associated with workplace spirituality. These factors can have job dissatisfaction, decreased loyalty, increased 
turnover, attrition, lower productivity, poor performance, and an overall environment of discontent.

\section{Theoretical contribution}

This study has made some theoretical contributions to the literature. First, a few extant studies have produced findings that suggest the organizationally desirable influence of workplace spirituality on POS and job performance. For the applied purpose, there is a need for a significant number of studies on the relationships. This study has added to the budding workplace spirituality, perceived organizational support, and job performance literature. Secondly, the findings that workplace spirituality positively predicts POS and job performance support confirm the affective event theory. Third, this study added to the emerging empirical evidence that gender is a less distinguishing factor in employees' work attitudes and behavior (Harrison, 2019; Liu et al., 2019). This growing body of knowledge calls for a common phenomenon to reexamine gender as a control variable in organizational behavior studies. These emerging research findings have plausible explanations in equal rights, inclusion agenda, and near absence of gender-based employment policy. And fourth, workplace spirituality, perceived organizational support, and job performance questionnaires were developed in a context alien to the environment of this study. However, based on observed satisfactory reliability and validity indices, this study confirms the psychometric properties of the measures in the Nigerian context.

\section{Implication for Practice}

This study revealed some information on workplace spirituality, POS, and job performance relevant to practice. For instance, the composite analysis revealed that workplace spirituality contributes positively and primarily to POS. Still, dimensional analysis shows that the only alignment between organizational and individual values and enjoyment at work dimensions made a vast contribution to the five workplace spirituality dimensions. Through WPS, efforts should enhance POS by achieving congruence in employees and corporate profits and providing a pleasant work environment. This recommendation reflects the person-organization fit theory and happy worker-productivity hypothesis. These could be achieved through recruitment and selection, training, rituals, policies, and employee-friendly rules. As a strategy, candidates with similar values as the organizations should be of choice to organizations. Employees should work as appropriate and be exposed to training that would teach them the organization's benefits. Employees should be made to experience and observed the rituals that depict the values of the organization. 
The composite analysis also revealed that workplace spirituality made a positive and massive impact on job performance. However, the five dimensions' investigation revealed that the only positive and significant relationship was between the team's sense of community dimension, in-role performance, extra-role-organization, and between a sense of contribution and the community extra-role behavior-individual. The finding also revealed that the team's sense of community explained more variance in in-role performance and extra-role behavior-organization than the combined four dimensions. These findings practically implied that searching for in-role performance and extra-role behavior-organization through workplace spirituality should enhance the team's sense of community. In contrast, searching for extra-role behavior-individual through workplace spirituality should improve an understanding of the community's contribution.

\section{Limitation}

This study revealed that workplace spirituality affects POS and job performance in an organizationally desirable direction, with some limitations that should guide interpretation, application of the findings, and future research. The present study is correlational, and such research design does not identify nor make possible interpretations of a causal relationship. Future studies should explore field experiments and longitudinal studies to achieve causal analysis and investigate potential mediators and moderators' relationships. The sample size used in this study can only see significance if the population effect size is medium. The plausibly accounts for the nonsignificant results obtained from the analysis of workplace spirituality dimensions and job performance. It suggested that studies on workplace spirituality and job performance should use a sample size to detect significance if it exists even when the population effect size is small. The population of this study was university administrative employees of a university.

In contrast, every job has its peculiarity, thus generalizing findings from this study to other unrelated tasks may not be justified. Subsequent studies should collect a sample that represents various jobs to enable results generalization. Workplace spirituality has attracted some models with related but also diverse dimensions. There is a need to examine these models related to psychometric properties to guide workplace spirituality studies.

\section{REFERENCES}

Aboobaker, N., Edward, M., \& Zakkariya, K. A. (2019). Workplace spirituality, employee well-being, and intention to stay: A multi-group analysis of teachers' 
career choice. International Journal of Educational Management, 33(1), 28-44. https://doi.org/10.1108/IJEM-02-2018-0049

Afsar, B., \& Badir, Y. (2017). Workplace spirituality, perceived organizational support and innovative work behavior: The mediating effects of personorganization fit. Journal of Workplace Learning, 29(2), 95-109. https://doi.org/10.1108/JWL-11-2015-0086

Agu, J. C. (2021). Influence of stress on staff job performance: A study of Isu local government area. International Journal of Innovative Psychology and Social Development, 9(1), 41-51.

Akhtar, M. W., Syed, F., Husnain, M., \& Naseer, S. (2019). Person-organization fit and innovative work behavior: The mediating role of perceived organizational support, affective commitment, and trust. Pakistan Journal of Commerce and Social Sciences (PJCSS), 13(2), 311-333.

Alghamdi, S. A. (2020). The impact of HR strategy on organizational effectiveness. American Journal of Theoretical and Applied Business, 6(4), 91-97. https://doi.org/10.11648/j.ajtab.20200604.16

Al-Hawary, S. I. S., \& Nusair, W. K. I. (2017). Impact of human resource strategies on perceived organizational support at Jordanian public universities. Global Journal of Management and Business Research, 17(1), 68-82. https://journalofbusiness.org/index.php/GJMBR/article/view/2184

Ashmos, D. P., \& Duchon, D. (2000). Spirituality at work: A conceptualization and measure. Journal of Management Inquiry, 9(2), 134-145. https://doi.org/10.1177/105649260092008

Bandsuch, M. R., \& Cavanagh, G. F. (2005). Integrating spirituality into the workplace: Theory and practice. Journal of Management, Spirituality, and Religion, 2(2), 221-254. https://doi.org/10.1080/14766080509518581

Baruch, Y., \& Holtom, B. C. (2008). Survey response rate levels and trends in organizational research. Human Relations, 61(8), 1139-1160. https://doi.org/10.1177/0018726708094863

Becker, G. S. (2009). Human capital: A theoretical and empirical analysis, with special reference to education. University of Chicago Press.

Beheshtifar, M., \& Zare, E. (2012). Effect perceived organizational support on employees' attitudes toward work. Science Series Data Report, 4(9), 28-34.

Bella, R. L. F., Quelhas, O. L. G., Ferraz, F. T., \& Bezerra, M. J. S. (2018). Workplace spirituality: Sustainable work experience from a human factors perspective. Sustainability, 10(6), 1887. https://doi.org/10.3390/su10061887 
Biswakarma, G. (2018). Impact of workplace spirituality on employee productivity in Nepalese hospitality organizations. Journal of Tourism and Hospitality Education, 8, 62-76. https://doi.org/10.3126/jthe.v8i0.20011

Bożek, A., Nowak, P. F., \& Blukacz, M. (2020). The relationship between spirituality, health-related behavior, and psychological well-being. Frontiers in Psychology, 11, 1997. https://doi.org/10.3389/fpsyg.2020.01997

Brace, I. (2018). Questionnaire design: How to plan, structure, and write survey material for effective market research. Kogan Page Publishers.

Caesens, G., Stinglhamber, F., Demoulin, S., De Wilde, M., \& Mierop, A. (2019). Perceived organizational support and workplace conflict: The mediating role of failure-related trust. Frontiers in Psychology, 9(2704). https://doi.org/10.3389/fpsyg.2018.02704

Chia, S. M., \& Kee, D. M. H. (2018). Workplace bullying and task performance: A study on salespeople in retail industry. Management Science Letters, 8(6), 707716. https://doi.org/10.5267/j.msl.2018.4.011

Choi, Y. (2019). A study of the effect of perceived organizational support on the relationship between narcissism and job-related attitudes of Korean employees. Cogent Business and Management, 6(1), 1573486. https://doi.org/10.1080/23311975.2019.1573486

Cohen, J. (1988). Statistical power analysis for the behavioral sciences. Laurence Erlbaum Associates.

Colquitt, J. A., Lepine, J. A., \& Wesson, M. J. (2019). Organizational behavior: Improving performance and commitment in the workplace (6th ed.). McGrawHill.

Davidescu, A. A., Apostu, S.-A., Paul, A., \& Casuneanu, I. (2020). Work flexibility, job satisfaction, and job performance among Romanian employees: Implications for sustainable human resource management. Sustainability, 12(15), 6086. https://doi.org/10.3390/su12156086

Dewberry, C. (2004). Statistical methods for organizational research: Theory and practice. Psychology Press.

Eagly, A., \& Wood, W. (Eds.). (2012). Social role theory. In P. A. M. Van Lange, A. W. Kruglanski, \& E. T. Higgins (Eds.), Handbook of theories of social psychology, (Vol 2, 458-476). Sage Publications.

Eisenberger, R., Cummings, J., Armeli, S., Lynch, P. (1997). Perceived organizational support, discretionary treatment, and job satisfaction. Journal of Applied Psychology, 82(5), 812- 820

Eisenberger, R., Huntington, R., Hutchison, S., \& Sowa, D. (1986). Perceived organizational support. Journal of Applied Psychology, 71(3), 500-507. 
Fanggidae, R. E., Kurniawati, M., \& Bahweres, H. (2020). The effect of workplace spirituality and employee performance: Perspective of Islamic work ethics case study on BTPN Syariah, Kupang. 2nd International Seminar on Business, Economics, Social Science and Technology (ISBEST 2019),

Fernando, W. H. M., Yusoff, S. K. M., Khatibi, A., Azam, S. F., \& Sudasinghe, S. (2020). Human capital practices impact on organizational performance. European Journal of Human Resource Management Studies, 4(2), 1-19. https://doi.org/10.5281/zenodo.3781297

Field, A. (2018). Discovering statistics using IBM SPSS (5th ed.). SAGE Publications.

Giacalone, R. A., \& Jurkiewicz, C. L. (2003). Toward a science of workplace spirituality. In R. A. J. Giacalone, Carole L (Ed.), Handbook of workplace spirituality and organizational performance (pp. 3-28). ME Sharpe.

Girdwichai, L., \& Sriviboon, C. (2020). Employee motivation and performance: Do the work environment and the training matter? Journal of Security and Sustainability Issues, 9(1), 42-54. http://doi.org/10.9770/jssi.2020.9.J(4)

Haddon, J. (2018). The impact of employees' well-being on performance in the workplace. Strategic Human Resource Review, 17(2), 72-75. https://doi.org/10.1108/SHR-01-2018-0009

Harrison, J. (2019). Student nurses' gender role is a predictor of caring behaviors and critical thinking. Evidence-Based Nursing, 22(3), 89-89. http://dx.doi.org/10.1136/ebnurs-2018-103029

Hayes, A. F. (2017). Introduction to mediation, moderation, and conditional process analysis: A regression-based approach. Guilford Publications.

Howitt, D., \& Cramer, D. (2017). Understanding statistics in psychology with SPSS. Pearson Education.

Hvidt, N. C., Nielsen, K. T., Kørup, A. K., Prinds, C., Hansen, D. G., Viftrup, D. T., Hvidt, E. A., Hammer, E. R., Falkø, E., \& Locher, F. (2020). What is spiritual care? Professional perspectives on the concept of spiritual care identified through group concept mapping. BMJ Open, 10(12), e042142. http://dx.doi.org/10.1136/bmjopen-2020-042142

Iksan, R., Sukoroto, \& Haryono, S. (2020). Examining the effect of workplace spirituality on job performance: A study from Indonesia. International Journal of Engineering Technologies and Management Research, 7(4), 20-30. http://dx.doi.org/10.29121/ijetmr.v7.i4.2020.566

Imran, M. Y., Elahi, N. S., Abid, G., Ashfaq, F., \& Ilyas, S. (2020). Impact of perceived organizational support on work engagement: Mediating mechanism of thriving and flourishing. Journal of Open Innovation: Technology, Market, and Complexity, 6(3), 82. https://doi.org/10.3390/joitmc6030082 
Indradevi, R. (2020). Workplace spirituality: Successful mantra for modern organization. Journal of Critical Review, 7(6), 437-440. http://dx.doi.org/10.31838/jcr.07.06.77

Jena, L. K. (2021). Does workplace spirituality lead to raising employee performance? The role of citizenship behavior and emotional intelligence. International Journal of Organizational Analysis, ahead-of-print. https://doi.org/10.1108/IJOA-06-2020-2279

Kaur, S. (2017). Perceived organizational support and affective commitment: A demographic analysis. IOSR Journal of Business and Management, 19(1), 5459. https://doi.org/10.9790/487x-1901045459

Koti, G., \& Kinange, U. (2021). A study on the association between workplace spirituality and job stress: A review. International Journal of Creative Research Thoughts, 9(1), 12-14.

Kuswati, Y. (2020). The effect of motivation on employee performance. Budapest International Research and Critics Institute (BIRCI-Journal): Humanities and Social Sciences, 3(2), 995-1002. https://doi.org/10.33258/birci.v3i2.928

Landy, F. J. (2019). Work in the 21st century: An introduction to industrial and organizational psychology (6th ed.). John Wiley \& Sons.

Leeper, T. J. (2019). Where have the respondents gone? Perhaps we ate them all. Public Opinion Quarterly, 83(S1), 280-288. https://doi.org/10.1093/poq/nfz010 Liu, N.-Y., Hsu, W.-Y., Hung, C.-A., Wu, P.-L., \& Pai, H.-C. (2019). The effect of gender role orientation on student nurses' caring behavior and critical thinking. International Journal of Nursing Studies, 89, 18-23. https://doi.org/10.1016/j.ijnurstu.2018.09.005

Luiten, A., Hox, J., \& de Leeuw, E. (2020). Survey nonresponse trends and fieldwork effort in the 21st century: Results of an international study across countries and surveys. Journal of Official Statistics, 36(3), 469-487. http://dx.doi.org/10.2478/JOS-2020-002

Maan, A. T., Abid, G., Butt, T. H., Ashfaq, F., \& Ahmed, S. (2020). Perceived organizational support and job satisfaction: A moderated mediation model of proactive personality and psychological empowerment. Future Business Journal, 6(1). https://doi.org/10.1186/s43093-020-00027-8

Mahesh, K., \& Saravanakumar, G. (2020). A study on relationship between ERM and organizational performance. Journal of Emerging Technologies and Innovative Research, 7(8), 1240-1248.

Mariani, K., Asmony, T., \& Nurmayanti, S. (2020). The effects of workplace spirituality on employee engagement and organizational citizenship behavior. 
International Journal of Innovative Science, Engineering and Technology, 7(8), 220-233.

Milliman, J., Czaplewski, A. J., \& Ferguson, J. (2003). Workplace spirituality and employee work attitudes: An exploratory empirical assessment. Journal of Organizational Change Management, 16(4), 426-447.

https://doi.org/10.1108/09534810310484172

Mirjana, P. B., Ana, A., \& Marjana, M.-S. (2018). Examining determinants of entrepreneurial intentions in Slovenia: Applying the theory of planned behavior and an innovative cognitive style. Economic research-Ekonomska istraživanja, 31(1), 1453-1471. https://doi.org/1410.1080/1331677X.1332018.1478321.

Moon, T.-W., Youn, N., Hur, W.-M., \& Kim, K.-M. (2020). Does employees' spirituality enhance job performance? The mediating roles of intrinsic motivation and job crafting. Current Psychology, 39(5), 1618-1634. https://doi.org/10.1007/s12144-018-9864-0

Nwanzu, C. L., \& Babalola, S. S. (2020). Examining the moderating role of workload in the relationship between emotional intelligence and caring behavior in healthcare organizations. International Journal of Business Science and Applied Management, 15(1), 17-29.

Okeke, M., Onuorah, A., \& Evbota, J. (2016). Influence of affective events on job satisfaction: A study of selected service enterprises in Edo state. International Journal of Social Sciences and Humanities Review, 6(1), 68-79.

Organ, D. W. (1988). Organizational citizenship behavior: The good soldier syndrome (First ed.). HD.C. Heath and Company.

Park, S., Oh, S., \& Lee, Y. (2020). The relationships between person-organization value fit and employee attitudes in a Korean government sector. The International Journal of Human Resource Management, 31(16), 2089-2114. https://doi.org/10.1080/09585192.2018.1431954

Perera, K., \& Weerakkody, W. (2018). The impact of human capital and social capital on employee performance: A study of employees in small-scale industry enterprises in the western province of Sri Lanka. Kelaniya Journal of Human Resource Management, 13(1), 38-48. http://doi.org/10.4038/kjhrm.v13i1.48

Petchsawang, P., \& Duchon, D. (2012). Workplace spirituality, meditation, and work performance. Journal of Management, Spirituality, and Religion, 9(2), 189208. https://doi.org/10.1080/14766086.2012.688623

Pierce, J. L., Gardner, D. G., Cummings, L. L., \& Dunham, R. B. (1989). Organization-based self-esteem: Construct definition, measurement, and validation. Academy of Management Journal, 32(3), 622-648. https://doi.org/10.5465/256437 
Rajper, Z. A., Ghumro, I. A., \& Mangi, R. A. (2020). The impact of person-job fit and person-organization fit on employee job performance: A study among employees of services sector. Abasyn University Journal of Social Sciences, 13(1), 54-65. https://doi.org/10.34091/JASS.13.1.05

Ranasinghe, V. R., \& Samarasinghe, S. M. (2019). The effect of workplace spirituality on innovative work behavior. International Business Research, 12(12), 29-38. https://doi.org/10.5539/ibr.v12n12p2

Rathee, R., \& Rajain, P. (2020). Workplace spirituality: A comparative study of various models. Jindal Journal of Business Research, 9(1), 27-40. https://doi.org/10.1177/2278682120908554

Rego, A., \& Cunha, M. P. E. (2008). Workplace spirituality and organizational commitment: An empirical study. Journal of Organizational Change Management, 21(1), 53-75. https://doi.org/10.1108/09534810810847039

Robbins, S. P., Judge, T. A., \& Breward, K. (2018). Essentials of organizational behavior (First Canadian Edition ed.). Pearson Education.

Robbins, S. P. J., Timothy A., \& Breward, K. (2019). Organizational behavior (18th ed.). Pearson Educations.

Rodríguez-Ardura, I., \& Meseguer-Artola, A. (2020). How to prevent, detect and control common method variance in electronic commerce research. Journal of Theoretical and Applied Electronic Commerce Research, 15(2), I-V. https://doi.org/10.4067/S0718-18762020000200101.

Salcedo, A. V., \& Lazatin, J. R. B. (2021). Workplace spirituality as a mediator to individual spirituality and organizational performance in a hospitality business: An evidence from Hotel X, Clarkfield, Angeles City, Pampanga, Philippines. International Journal of Creative Business and Management, 1(1), 21-37. https://doi.org/10.31098/ijcbm.v1i1.3881

Sayadi, Y., Hoveida, R., Siadat, S. A., \& Rajaeepour, S. (2015). The relationship between perceived organizational support and organization-based self-esteem among teachers in Iran. Journal of Information and Knowledge Management, $5(5), 20-24$

Shrestha, A. K., \& Jena, L. K. (2021). Interactive effects of workplace spirituality and psychological capital on employee negativity. Management and Labor Studies, 46(1), 59-77. https://doi.org/10.1177/0258042X20962994

Smith, J. A., \& Rayment, J. J. (2007). The global SMP fitness framework: A guide for leaders exploring the relevance of spirituality in the workplace. Management Decision, 45(2), 217-234. https://doi.org/10.1108/00251740710727250

Suherman, U. D. (2020). Analysis of spirituality effect on workplace and work motivation on employee performance bank Syariah Mandiri in Jawa Barat 
region. Li Falah: Jurnal Studi Ekonomi dan Bisnis Islam, 5(2), 74-89. http://dx.doi.org/10.31332/lifalah.v5i2.2307

Tamunomiebi, M. D., \& Mezeh, A. A. (2021). Workplace stressors and employee performance: A conceptual review. Asian Journal of Economics, Business, and Accounting, 21(4), 57-66. https://doi.org/10.9734/ajeba/2021/v21i430371

Tantua, E., \& Osuamkpe, N. E. (2020). Workplace spirituality and employee performance of manufacturing firms in River State, Nigeria. International Academy Journal of Management Annals, 6(1), 1-12.

Tarmidi, D., \& Arsjah, R. (2019). Employee and organizational performance: Impact of employee internal and external factors, moderated by online. Application Journal of Resources Development And Management, 57, 30-37.

Tayebiniya, N. K., \& Khorasgani, N. S. (2018). The relationship between workplace spirituality and job performance among staff of Azad Islamic University, Iran. Humanities and Social Sciences Reviews, 6(1), 14-18. https://doi.org/10.18510/hssr.2018.613

ur Rashid, M., Manzoor, H., \& Ghani, U. (2019). Exploring and conceptualizing workplace spirituality in Islamic Banks. Business and Economic Review, 11(2), 131-148. https://doi.org/10.22547/BER/11.2.7

Viswesvaran, C., \& Ones, D. S. (2000). Perspectives on models of job performance. International Journal of Selection and Assessment, 8(4), 216-226.

Weiss, H. M., \& Cropanzano, R. (1996). Affective events theory: A theoretical discussion of the structure, causes, and consequences of affective experiences at work. In B. M. Staw \& L. L. Cummings (Eds.), Research in organizational behavior: An annual series of analytical essays and critical reviews, Vol. 18. (pp. 1-74). Elsevier Science/JAI Press.

Williams, L. J., \& Anderson, S. E. (1991). Job satisfaction and organizational commitment as predictors of organizational citizenship and in-role behaviors. Journal of Management, 17(3), 601-617. https://doi.org/10.1177/014920639101700305

Zmud, R. W., \& Boynton, A. C. (1991). Survey measures and instruments in MIS: Inventory and appraisal. In K. Kraemer (Ed.), The information systems research challenge: Survey research methods (Vol. 3, pp. 149-180). Harvard Business School Boston.

Zoghbi-Manrique-de-Lara, P., \& Sharifiatashgah, M. (2020). An affective events model of the influence of the physical work environment on interpersonal citizenship behavior. Revista de Psicología del Trabajo y de las Organizaciones, 36(1), 27-37. https://doi.org/10.5093/jwop2019a27 


\section{Adopted Scales}

\section{WORKPLACE SPIRITUALITY}

\section{Team's sense of community}

1. People in my team/group feel as if they were part of a family.

2. My team/group promotes the creation of a spirit of community.

3. I feel that the members of my team/group support each other.

4. I feel that the members of my team/group care about each other.

5. I feel that a common purpose links the members of my team/group.

\section{Alignment between organizational and individual values}

6. I feel positive about the values prevailing in my organization.

7. People feel good about their future with the organization.

8. My organization respects my "inner life."

9. My organization helps me to live in peace/harmony with myself.

10. The leaders of my organization try to be helpful to the larger social good of the community.

\section{Sense of contribution to the community}

11. My work is connected with what I think is important in life.

12. I see a connection between my work and the larger social good of my community.

13. When working, I feel helpful for the whole society.

\section{Sense of enjoyment at work}

14. I experience joy in my work.

15. Most days, I feel joy when coming to work.

\section{Opportunities for the inner life}

16. My spiritual values are not valued in my workplace. (R)

17. In my workplace, there is no room for my spirituality. (R)

Note. (R) indicates reverse coded item.

\section{PERCEIVED ORGANIZATIONAL SUPPORT}

1. The organization values my contribution to its well-being.

2. The organization fails to appreciate any extra effort from me. (R)

3. The organization would ignore any complaints from me. (R)

4. The organization cares about my well-being.

5. Even if I did the best job possible, the organization would fail to notice. (R)

6. The organization cares about my general satisfaction at work.

7. The organization shows very little concern for me. (R)

8. The organization takes pride in my accomplishments at work 


\section{JOB PERFORMANCE}

\section{Performance of in-role behavior}

1. Adequately completes assigned duties.

2. Fulfiled responsibilities specified in the job description.

3. Performs tasks that are expected of him/her.

4. Meets formal requirements of the job.

5. Engages in activities that will directly affect his/her performance evaluation.

6. Neglects aspect of the job he/she is obligated to perform. (R)

7. Fails to perform essential duties. (R)

\section{Organization citizenship behavior (individual)}

8. Helps others who have been absent.

9. Helps others who have heavy workloads.

10. Assists supervisor with his/her work (when not asked).

11. Takes time to listen to co-workers' problems and worries.

12. Goes out of ways to help new employees.

13. Takes a personal interest in other employees.

14. Passes along information to co-workers.

\section{Organization citizenship behavior (organization)}

15. Attendance at work is above the norms.

16. Gives advance notice when unable to come to work.

17. Takes undeserved work breaks. (R)

18. Great deal of time spent with personal phone conversation. (R)

19. Complain about insignificant things at work. (R)

20. Conserves and protects organizational property.

21. Adheres to informal rules devised to maintain order.

Note. (R) indicates reverse-coded item.

Dr. Chiyem Lucky Nwanzu is a Ph.D. holder in Industrial/Organizational Psychology and a Lecturer in the Department of Psychology, Delta State University, Abraka, Nigeria. His research interests are workplace attitude and behavior, organization sustainability, and change management.

Mr. Sunday Samson Babalola (Corresponding author) is a Professor of Management with over 20 years in teaching, research, and administration in higher educational institutions. He is an NRF-C rated scientist. His research benefited from a solid background in quantitative analysis, with working knowledge in qualitative analysis. His focus is on applying psychological processes to diverse work behaviors with contributions to theory building and methodology. 